\title{
Études/Inuit/Studies
}

\section{Revue des thèses}

\section{Survey of dissertations}

Volume 40, numéro 1, 2016

URI : https://id.erudit.org/iderudit/1040156ar

DOI : https://doi.org/10.7202/1040156ar

Aller au sommaire du numéro

\section{Éditeur(s)}

Association Inuksiutiit Katimajiit Inc.

Centre interuniversitaire d'études et de recherches autochtones (CIÉRA)

ISSN

0701-1008 (imprimé)

1708-5268 (numérique)

Découvrir la revue

Citer ce document

(2016). Revue des thèses / Survey of dissertations. Études/Inuit/Studies, 40(1),

251-266. https://doi.org/10.7202/1040156ar d'utilisation que vous pouvez consulter en ligne.

https://apropos.erudit.org/fr/usagers/politique-dutilisation/ 


\title{
Revue des thèses/ \\ Survey of dissertations
}

\author{
ARISMENDI, Jacquel Lynn \\ 2015 Ancient mtDNA Sequences from Prebistoric North American Arctic \\ Populations, Ph.D., University of Utah, Salt Lake City, 152 pages.
}

This study set out to sequence the hypervariable segment-I (HVS-I) of the mitochondrial genome from prehistoric skeletal remains associated with Aleut, Sadlermiut, Dorset, and Thule groups in northern North America in an effort to gain insight into their genetic prehistories. Sequences obtained from said ancient populations (Aleut, $n=6$; Sadlermiut, $n=7$; Thule, [partial sequences] $n=3$ ) were compared to each other as well as those from contemporary and prehistoric populations in the surrounding area. The prehistoric populations under investigation harbored matrilineages typically found in circum-Arctic populations throughout time: A2, A2a, A2b1, D2/D2a'b/D2a/D2a1 and D4b1a2a1. Ancient Aleuts exhibited HVS-I polymorphisms associated with haplogroups A2a, D2, and D2a'b, while the Sadlermiut were characterized as A2b1 and D4b1a2a1. Partial Thule HVS-I sequences indicate A2 but preclude definitive assignment to A2, A2a, or A2b1 until the remaining portion of HVS-I is sequenced. The results indicate that ancient Aleuts across time exhibit affinities with the Unangax? (modern Aleuts); however, population movement or genetic exchange with neighbors to the east cannot be ruled out at this time. Ancient Aleuts were also found to have a greater matrilineal genetic similarity to Chukotkan populations (Chukchi and Siberian Yuit), rather than those from Kamchatka (Koryak and Itel'men). This genetic similarity/dissimilarity provides additional corroboration for colonization of the Aleutian archipelago being initiated from the east rather than the west. The isolated eastern Arctic Sadlermiut population, on the other hand, was shown to have affinities with contemporary Eskimo (Inuit and Iñupiat). The implications of this points towards the Sadlermiut having Neo-Eskimo rather than Paleo-Eskimo ancestry and echoes previous findings of matrilineal discontinuity in the eastern Arctic. The mtDNA (mitochondrial deoxyribonucleic acid) profiles of the ancient populations in this study are also congruent with results from other mtDNA 
studies indicating that the genetic prehistory of the Neo-Eskimo was distinct from that of the Paleo-Eskimo and inhabitants of the Aleutians. Overall the findings in this study speak to matrilineal genetic relationships of prehistoric and contemporary populations in the most northern stretches of the New World while touching upon population movements in the region.

Séquences anciennes d'ADN mitochondrial dans les populations arctiques préhistoriques d'Amérique du Nord, Ph.D., University of Utah, Salt Lake City, 152 pages.

Cette étude entreprend de séquencer le segment I (HVS-I) du génome mitochondrial dans les ossements préhistoriques associés aux groupes des Aléoutes, Sadlermiut, Dorsétiens et Thuléens au nord de l'Amérique du Nord, pour tenter d'avoir un aperçu de leur préhistoire génétique. Les séquences obtenues dans ces populations anciennes (Aléoutes, $n=6$; Sadlermiut, $n=7$; Thuléens [séquences partielles], $\mathrm{n}=3$ ) ont été comparées entre elles ainsi qu'avec celles des populations contemporaines et préhistoriques des régions environnantes. Les populations préhistoriques à l'étude ont montré des matrilignages que l'on découvre généralement dans les populations circumpolaires au fil du temps: A2, A2a, A2b1, D2/D2a'b/D2a/D2a1 et D4b1a2a1. Les anciens Aléoutes montraient un HVS-I polymorphe associé aux haplogroupes A2a, D2 et D2a'b, tandis que les Sadlermiut se caractérisaient par les haplogroupes A2b1 et D4b1a2a1. Chez les Thuléens, des séquences partielles du HVS-I indiquaient l'haplogroupe A2 mais il était impossible de préciser une attribution à A2, A2a ou A2b1 tant que la partie restante du HVS-I n'avait pas été séquencée. Les résultats montrent que les anciens Aléoutes, à travers le temps, présentent des affinités avec les Unangax (Aléoutes modernes); cependant, on ne peut exclure à ce stade qu'il y ait eu des mouvements de population ou des échanges génétiques avec des peuples voisins. On a également découvert chez les anciens Aléoutes une plus grande similitude génétique matrilinéaire avec les populations parlant les dialectes tchouktches (Tchouktches et Yuit sibériens) plutôt qu'avec celles du Kamchatka (Koriak et Itelmènes). Ces similitudes et différences génétiques corroborent le fait que les îles aléoutiennes ont bien été colonisées à partir de l'est plutôt que de l'ouest. Par contre, la population des Sadlermiut, isolée dans l'Arctique de l'Est, présente des affinités avec les Esquimaux contemporains (Inuit et Inupiat). Cela implique que les Sadlermiut seraient d'ascendance néoesquimaude plutôt que paléoesquimaude, en plus de faire écho à de précédentes découvertes de discontinuité matrilinéaire dans l'Arctique de l'Est. Les profils d'ADN mitochondrial des populations anciennes à l'étude concordent également avec les résultats d'autres études d'ADN mitochondrial indiquant que la préhistoire génétique des Néoesquimaux était distincte de celle des Paléoesquimaux et des habitants des îles Aléoutiennes. Dans l'ensemble, les résultats de cette étude évoquent des relations génétiques matrilinéaires entre les populations préhistoriques et contemporaines des régions 
les plus reculées du Nouveau Monde, tout en effleurant l'idée de mouvements de populations dans la région.

BROWER, Pearl Kiyawn

2016 Tumitchiat: Iñuqqaat Aullarrisiatun Ilisagivit, A New Pathway: Indigenous Leadership in Higher Education, Ph.D., University of Alaska Fairbanks, Fairbanks, 231 pages.

After centuries of colonization and assimilation policies in education, Indigenous people across our world are making commitments to nurture the next generation of Indigenous leaders. One area of focus is on Indigenous leadership through various forms of Higher Education. This dissertation supports the need for Indigenous leadership programs that have a foundation in Indigenous ways of knowing and learning and suggests a definition of what Indigenous leadership embodies. Specific Indigenous leadership programs are described. Within the United States, tribal colleges are unique entities, but they share the same goals. These institutions create opportunities for hope and sustained Indigenous self-determination through their students, who are the next generation of Indigenous leaders. A broad review of tribal colleges is presented here. Then a particular tribal college, Ilisagvik College, located in Barrow, Alaska, is discussed in more detail. The research also illuminates circumstances at the University of Hawai'i (UH), a settler-colonial institution that has recently decided to become a Native Hawaiian $(\mathrm{NH})$ serving institution. How is this new responsibility viewed by UH's Indigenous leaders? I conclude with an overview and syllabus for an Arctic Indigenous leadership program to be implemented at Ilisagvik College. The intent is to provide a path that others may use to create their own programs to meet their Indigenous communities' needs.

Tumitchiat. Iñuqqat Aullarrisiatun Ilisagivit - Une nouvelle voie. La formation de dirigeants autochtones dans les établissements d'enseignement supérieur, Ph.D., University of Alaska Fairbanks, Fairbanks, 231 pages.

Après des siècles de colonisation et de politiques d'assimilation par le biais de l'enseignement, les peuples autochtones du monde entier s'engagent à former la prochaine génération de dirigeants autochtones. Ils se préoccupent en particulier de la formation de ces derniers dans les diverses filières de l'enseignement supérieur. Cette thèse prône la nécessité, pour les programmes de formation destinés aux futurs dirigeants autochtones, de se fonder sur les modes autochtones de savoir et d'acquisition des connaissances et propose une définition de ce que représente le leadership autochtone, avant de décrire certains programmes de formation de dirigeants autochtones. Aux États-Unis, les établissements autochtones de premier cycle (Colleges) sont des entités indépendantes, mais ayant des objectifs communs. Ces institutions créent, avec espoir et énergie, des opportunités 
d'autodétermination autochtone par l'intermédiaire de leurs étudiants, qui représentent la prochaine génération de dirigeants autochtones. Nous passons en revue bon nombre d'établissements autochtones de premier cycle avant de discuter en détail de l'un d'entre eux en particulier, le Ilisagivik College, situé à Barrow en Alaska. Cette recherche éclaire aussi la situation de University of Hawai'i (UH), une institution coloniale qui a récemment décidé de se mettre au service des Autochtones hawaiiens. Comment les dirigeants autochtones de UH considèrent-ils cette nouvelle responsabilité? Je termine par l'examen du syllabus d'un programme de formation de dirigeants autochtones dans l'Arctique devant être mis en ouvre au Iḷisagivik College et dont l'objectif est d'ouvrir la voie à d'autres, afin qu'ils puissent créer leurs propres programmes pour répondre aux besoins de leurs communautés autochtones.

CARL, Erica

2015 Yup'ik Ortbodox Christianity: An Ethnographic Grounded Theory Description, Ph.D., Biola University, La Mirada, 297 pages.

This grounded-theory ethnography explores the phenomenon of Yup'ik Orthodoxy, which is the practice of Eastern Orthodox Christianity among the Native Alaskan Eskimo people of Southwestern Alaska. After provided the reader with a brief background on the major factors influencing modern Yup'ik life and methodological justifications, the three major areas of baptism, naming, and death are explored through participant observation and interviews. Baptism is explored as a means of incorporation, creating familial relationships based on the church and allowing a public expression of Hiebert's middle realm. Naming is a way of connecting the living with the dead, and, while it may have had pagan roots, today lends itself to a form of Christian social welfare. Death is seen by the Yup'ik Orthodox people as ephemeral, and while many death practices may also have had pagan roots, today the complex practices of mourning, burial, fasting, and feasting are explained by participants from a very Christian-yet very Yup'ikperspective. Yup'ik Orthodoxy is presented as a worldview rather than as a specific practice, both shaping and shaped by the identities of the people who practice and live this faith. This paper concludes that while pagan practices were clearly present at the time of evangelization, the Yup'ik Orthodox people are deeply Christian, and that many of their traditional forms and practices have been baptized and are now spoken of and explained in a Christian manner.

Le christianisme orthodoxe chez les Yupiit. Description ethnographique par théorisation ancrée, Ph.D., Biola University, La Mirada, 297 pages.

Cette étude ethnographique par théorisation ancrée explore le phénomène de l'orthodoxie chez les Yupiit, à savoir la pratique du christianisme oriental parmi ce peuple esquimau de l'Alaska du Sud-Ouest. Après avoir procuré au 
lecteur une brève mise en contexte des principaux facteurs influençant la vie des Yupiit modernes et des justifications méthodologiques, j'aborde les trois principaux domaines du baptême, de l'attribution du nom et de la mort au moyen d'une observation participante et d'entrevues. Le baptême est considéré comme un moyen d'incorporer, de créer des relations familiales enracinées dans l'Église et de permettre l'expression publique du "royaume du milieu» de Hiebert. L'attribution du nom est une manière de relier les vivants aux morts et, bien qu'elle puisse avoir des racines païennes, cette pratique se prête aujourd'hui à une forme de bien-être social chrétien. La mort est considérée comme éphémère chez les Yupiit orthodoxes, et bien que plusieurs pratiques mortuaires puissant avoir elles aussi des racines païennes, aujourd'hui les pratiques complexes du deuil, de l'enterrement, du jeûne et du festin sont expliquées par les participants selon une perspective très chrétienne - et néanmoins très yup'ik. Chez les Yupiit, l'orthodoxie se présente comme une vision du monde plutôt que comme une pratique spécifique, qui à la fois façonne et est façonnée par les identités du peuple qui pratique et vit sa foi. Cette thèse en conclut que, bien que les pratiques païennes aient été clairement présentes au moment de l'évangélisation, les Yupiit orthodoxes sont profondément chrétiens. Beaucoup de leurs pratiques et façons de faire traditionnelles ont été «baptisées" et ils en parlent et les expliquent dorénavant à la manière chrétienne.

\section{HEALEY, Gwen Katheryn}

2015 Inuit Family Perspectives and Stories About Sexual Health and Relationships in Nunavut, Ph.D., University of Toronto, Toronto, 259 pages.

High rates of sexually transmitted infections of chlamydia and gonorrhea were a concern among community members in Nunavut. The goal of this study was to explore the perspectives of Inuit youth and parents on the topic of sexual health and relationships. This qualitative participatory research study was conducted within an Indigenous knowledge framework with a focus on Inuit ways of knowing and storytelling. Interviews were conducted in 2011 in 3 Nunavut communities with 17 Inuit youth 16-19 years of age and 20 Inuit parents who had at least 1 teenage son or daughter 13-19 years of age. Parents linked their understandings of sexual health with a series of relocation events, which occurred in the Canadian Arctic in the mid-20th century. These relocation events led to widespread disruption of Inuit families, kinships, and attachments by separating young children from their primary caregivers for extended periods of time. The traditional communication pathway about sexual health and relationships was disrupted for many families during this time. Concurrent experiences of child sexual abuse among the parents in this study compounded the trauma of being separated from their families. Severed family attachments during the settlement period and child sexual abuse were the 
primary factors discussed by parents in this study as contributing to the current state of sexual health in Nunavut. Youth participants identified parents/caregivers as the preferred source of knowledge about sexual health and relationships, even if they were not learning from them at the present time. They also related sexual decision-making among youth to the broader community context and determinants of health, such as poverty. Taking these findings into account, rebuilding and strengthening family and community relationships can make significant positive contributions to sexual health and relationships by providing supportive networks for adolescents and revitalizing millennia-old pathways for knowledge sharing. Directions for public health include: supporting parentadolescent dialogue about sexual health; incorporating holistic individual and collective empowerment-based models for sexual health promotion; and supporting parents to heal from trauma and strengthen family relationships.

Points de vue et histoires familiales des Inuit au sujet de la santé sexuelle et des relations amoureuses au Nunavut, Ph.D., Université de Toronto, Toronto, 259 pages.

Les taux élevés de maladies sexuellement transmissibles telles que la chlamydia ou la gonorrhée étaient préoccupants dans les communautés du Nunavut. L'objectif de cette étude était d'aborder les points de vue des jeunes Inuit et de leurs parents sur le sujet de la santé sexuelle et des relations amoureuses. Cette recherche participative et qualitative a été menée dans le cadre théorique d'un savoir autochtone mettant l'accent sur la façon inuit de connaître et de raconter. En 2011, des entrevues ont été menées dans trois communautés du Nunavut auprès de 17 jeunes âgés de 16 à 19 ans et de 20 parents ayant au moins un fils ou une fille adolescent(e) âgé(e) de 13 à 19 ans. Les parents associaient leur compréhension de la santé sexuelle à une série de réinstallations qui se sont produites dans l'Arctique canadien au milieu du $\mathrm{XX}^{\mathrm{e}}$ siècle. Ces réinstallations ont provoqué un éclatement des familles inuit, des liens de parenté et des relations affectives en séparant les jeunes enfants de leurs parents nourriciers durant de longues périodes. Les voies de communication traditionnelles au sujet de la santé sexuelle et des relations amoureuses se sont interrompues dans de nombreuses familles à cette époque. À la même époque, des abus sexuels subis par certains parents de cette étude ont encore aggravé le traumatisme provoqué par la séparation familiale. La coupure qui s'est produite dans les affections familiales durant la période de réinstallation et les abus sexuels sur les enfants étaient pour les parents de cette étude les principaux facteurs déclenchants de l'état actuel de la santé sexuelle au Nunavut. Pour les jeunes participants, les parents ou parents nourriciers étaient la référence de prédilection pour ce qui était de la santé sexuelle et des relations amoureuses, même s'ils ne l'apprenaient pas d'eux à ce moment précis. Ils reliaient également les prises de décision relatives à la sexualité chez les jeunes au contexte élargi de la communauté et aux déterminants de la santé tels que la pauvreté. Si 
l'on prend en compte ces données, la reconstruction et le renforcement des relations familiales et communautaires peuvent apporter d'importantes et positives contributions à la santé sexuelle et aux relations amoureuses en procurant aux adolescents des réseaux de soutien et en revitalisant les canaux millénaires de transmission du savoir. En termes de santé publique, les directions à prendre sont: soutenir le dialogue entre parents et adolescents au sujet de la santé sexuelle; incorporer des modèles d'autonomisation holistiques, individuels et collectifs, dans la promotion de la santé sexuelle; et aider les parents à surmonter le traumatisme et à renforcer les relations familiales.

JACOBS, Annaliese

2015 Arctic Circles: The Franklin Family, Networks of Knowledge, and Early Nineteenth Century Arctic Exploration, 1818-1859, Ph.D., University of Illinois at Urbana-Champaign, Champaign, 428 pages.

This dissertation examines how the women of the family of the Arctic explorer Sir John Franklin (1786-1847) engaged with imperial and geographical networks of knowledge from 1818 to 1859. It argues that over this 40-year period the Franklin women (and especially John Franklin's second wife, Jane Franklin, and his niece, Sophia Cracroft) drew on their roles as wives, daughters, sisters, and nieces to lay claim to their moral authority to receive, evaluate, interpret, and circulate intelligence from the field, to act upon it, or to compel others to do so. They built this authority up haphazardly over time and space as they "careered" along with John Franklin from circles of polite science in London in the 1820 s to the penal colony of Van Diemen's Land (Tasmania), where he was the lieutenant governor from 1837 to 1843 , and to Britain in the 1840s and 1850s, where they organized expeditions to go in search of Franklin after he had disappeared in an attempt to chart the Northwest Passage in 1845. At each stage, the Franklin women actively engaged with (and derived connections, strategies, and information from) dynamic networks of imperial knowledge across a series of colonial, metropolitan, and extra-imperial sites. These included, but were not limited to, the changing circuits of scientific sociability, and trans-imperial networks of imperial humanitarianism, settlers, colonial governance, and science. In the webs of imperial knowledge in which they were entangled and which they wove, the Franklin women's authority was always gendered, precarious, and questioned, and this dissertation argues that they consistently shored it up by seeking to silence, calibrate, or otherwise reshape the characters and credibility of Indigenous people from Inuit interpreters to Tasmanian orphans. In doing so, they consistently engaged with Indigenous networks of knowledge, exchange, and resistance that were formed both within and outside imperial terrain from the Arctic to Van Diemen's Land. The Franklin women also tried either to co-opt or to subvert the vernacular agents of imperial industry, commerce, and expansion-whalers, fur traders, and settlers-who acted as 
intermediaries with Indigenous people, and with whom the Franklin women both made and discarded alliances as it suited them.

Les cercles arctiques. La famille Franklin, les réseaux du savoir et l'exploration de l'Arctique au début du XIX $X^{e}$ siècle, 1818-1859, Ph.D., University of Illinois at Urbana-Champaign, Champaign, 428 pages.

Cette thèse examine la façon dont les femmes de la famille de l'explorateur de l'Arctique, Sir John Franklin (1786-1847), se sont impliquées dans les réseaux impériaux du savoir géographique de 1818 à 1859. Elle démontre que, durant cette période de plus de 40 ans, les femmes de la famille Franklin (en particulier la seconde femme de John Franklin, Jane Franklin, et sa nièce, Sophia Cracroft) ont tiré parti de leur rôle d'épouse, de fille, de sœur et de nièce pour revendiquer une autorité morale leur permettant de recevoir, évaluer, interpréter et diffuser les informations en provenance du terrain, pour agir à ce sujet ou pour convaincre les autres de le faire. Leur autorité en la matière s'est accrue de façon aléatoire avec le temps et s'est élargie dans l'espace à mesure qu'elles "tanguaient" avec John Franklin depuis les cercles scientifiques de la bonne société à Londres dans les années 1820 jusqu'à la colonie pénitentiaire de la "Terre de Van Diemen" (la Tasmanie), dont il fut le lieutenant-gouverneur de 1837 à 1843, et en GrandeBretagne dans les années 1840 et 1850, lorsqu'elles organisèrent les expéditions devant aller à la recherche de Franklin après sa disparition lors de sa tentative de cartographier le passage du Nord-Ouest en 1845. À chacune de ces étapes, les femmes de la famille Franklin s'engageaient activement dans des réseaux dynamiques de savoir impérial (dont elles retiraient des relations, des stratégies et des informations), et dans une série de sites coloniaux, métropolitains ou situés hors de l'Empire. Parmi ceux-ci se trouvaient, entre autres, les circuits changeants de la sociabilité scientifique et les réseaux, qui couvraient tout l'Empire, de l'humanitarisme impérial, des colons, de la gouvernance coloniale et des scientifiques. Dans les filets du savoir impérial dans lesquels elles étaient prises et qu'elles contribuaient à tisser, l'autorité des femmes de la famille Franklin a toujours été sexuée, précaire et remise en question, et l'argument de cette thèse est qu'elles la consolidaient constamment en cherchant à réduire au silence, à évaluer, voire à reformuler les caractères et la crédibilité des Autochtones, depuis les interprètes inuit jusqu'aux orphelins de Tasmanie. Ce faisant, elles se confrontaient sans cesse aux réseaux de savoir, d'échanges et de résistance des Autochtones, qui se constituaient à la fois au sein du terrain impérial et en-dehors de celui-ci, de l'Arctique jusqu'à la Terre de Van Diemen. Les femmes de la famille Franklin s'efforçaient également de récupérer ou de circonvenir le menu peuple de l'industrie, du commerce et de l'expansion impériale - baleiniers, traiteurs de fourrure et colons - qui servaient d'intermédiaires auprès des peuples autochtones et avec lesquels elles contractaient des alliances qu'elles pouvaient rompre à leur gré. 


\section{McGRATH, Matthew}

2016 The Decline of the New Deal Fishery: Labor, Race, and Environment in the Western Alaskan Fisheries, 1930-1965, Ph.D., Carnegie Mellon University, Pittsburgh, 511 pages.

The fishermen of Western Alaska sought guarantees during the 1930s that would insulate them from chaotic salmon cycles, empty nets, and dangerous seas. Newly-created fishermen's unions had high expectation for federal assistance that would minimize occupational risk and insulate fishermen from "fishermen's luck." Working-class mutualism in this New Deal Fishery encouraged white CIO fishermen to overcome occupational divisions between skippers and crewmen, and to partially unite across racial lines with Native Alaskan residents in Bristol Bay and Kodiak. Yup'ik, Athabascan, and Aleut fishermen gained access to boat spots but still used a number of race-based strategies to negotiate inter-union structural discrimination. I argue that inter-union strife caused by unresolved racial inequalities combined with the state's ambivalence over the designation of fishermen as "workers" to influence a 1954 Federal Trade Commission decision to dissolve the fishermen's unions. These two inconsistencies-racism and contested legal statuses-were unaddressed by New Deal-era labor reforms. Craft union ideology based on racial privilege resurfaced when white employment privileges were threatened by job curtailments in the wake of declining salmon runs. Employment competition between white and Native fishermen led to a bitter wave of "bread and butter" anticommunism where each side red-baited the other to secure economic interests. Anticommunism fueled a vicious civil war in the Alaska Fishermen's Union. It attracted a red-hunting congressional committee to Alaska, fired the imaginations of ideologues, destroyed the union dream of a coastwise fish-price, and ultimately paved the way for an entrepreneurial fishery. The simultaneous lifting of a 50-year-old ban on power boats in Bristol Bay and the government's re-interpretation of fishermen's legal status added to these Cold War influences to create conditions for business "independence." Fishermen still attempted to re-establish the New Deal compact as late as 1965 by protesting the use of state-sponsored "cooperatives." Ultimately, de-unionization and the "decline" of the New Deal Fishery were conditioned by a combination of these cultural, racial, and environmental factors.

Le déclin des pêcheries du New Deal. Travail, race et environnement dans les pêcheries de l'ouest de l'Alaska, 1930-1965, Ph.D., Carnegie Mellon University, Pittsburgh, 511 pages.

Dans les années 1930, les pêcheurs de l'ouest de l'Alaska cherchaient à obtenir des garanties qui les protégeraient des cycles chaotiques du saumon, des filets vides et des mers dangereuses. Les tout nouveaux syndicats de marinspêcheurs plaçaient de grands espoirs dans l'aide fédérale censée atténuer les 
risques de leur métier et apporter aux pêcheurs une meilleure égalité des chances. La mutualité ouvrière de ces pêcheries du New Deal incitait les patrons pêcheurs (investisseurs) blancs à dépasser la division du travail entre capitaines et hommes d'équipage et à s'unir partiellement, à travers les lignes de division raciale, avec les résidents autochtones de la baie de Bristol et de Kodiak. Des pêcheurs yupiit, athapascans et aléoutes parvinrent à accéder aux zones de pêche des bateaux, mais ils utilisèrent quand même un certain nombre de stratégies fondées sur la race pour négocier une discrimination structurelle entre syndicats. J'avance que la grève intersyndicale causée par des inégalités raciales non résolues s'est combinée à l'ambiguité de l'État au sujet de la qualification des pêcheurs en "ouvriers" pour inciter la Commission fédérale du Commerce, en 1954, à dissoudre les syndicats de pêcheurs. Ces deux incohérences - le racisme et le flou quant au statut légal - ont été ignorées par les réformes du travail à l'époque du New Deal. L'idéologie des syndicats professionnels basés sur les privilèges raciaux a refait surface lorsque les privilèges des Blancs ont été menacés par des réductions d'emploi consécutivement au déclin de la remontée des saumons. La concurrence pour l'emploi entre les pêcheurs blancs et autochtones a mené à une vague amère d'anticommunisme lors de laquelle, pour gagner sa vie, chaque camp accusait l'autre d'être "rouge" pour assurer ses intérêts économiques. L'anticommunisme a alimenté un conflit haineux au sein du syndicat des pêcheurs de l'Alaska au point d'attirer un comité du congrès "chasseur de rouges"; il a enflammé l'imagination des idéologues, détruit le rêve d'une harmonisation des prix sur la côte, et a finalement ouvert la voie aux pêcheries entrepreneuriales. La levée simultanée d'une interdiction vieille de 50 ans sur les bateaux à moteur dans la baie de Bristol et la réinterprétation, par le gouvernement, du statut légal des pêcheurs se sont ajoutées à ces influences de la Guerre froide pour créer les conditions de "l'indépendance» entrepreneuriale. Les pêcheurs s'efforçaient toujours, aussi tard que 1965, de restaurer les conditions du New Deal en protestant contre les "coopératives" d'État. En fin de compte, la fin des syndicats et le "déclin" des pêcheries du New Deal ont été conditionnés par une combinaison de ces facteurs culturels, raciaux et environnementaux.

\section{MOSSAKOWSKI, Tomasz Filip}

2015 "The Sailors Dearly Love to Make Up": Cross-dressing and Blackface During Polar Exploration, Ph.D., University of London, King's College, London (UK), 323 pages.

This research project writes against the hegemonic narratives of polar exploration in the 19th and early 20th centuries. Using the published and unpublished diaries of explorers from 1819 to 1904, it asks how queer, critical race, and postcolonial critiques of the hyper-masculine, all-white image of the polar explorer can open up new understandings of polar spaces both in the nineteenth century and today, when similar nationalistic, colonial enterprises 
are at play. Primarily informed by Lisa Bloom's feminist, postcolonial review of American ideologies of polar exploration, this project discusses the large disparity between the intensely masculine image of the polar hero-adventurer and the particularly Anglo-American, but also Norwegian, tendency to perform in drag during polar expeditions. It also examines the high incidence of blackface theatre: in one of the whitest spaces conceivable, sailors donned the black mask to air a complex constellation of white, colonial, and class grievances and aspirations. Polar performance, which evolved to have its own idiosyncrasies shaped by the natural and social polar environment, affected colonial relations with Inuit, the stuff of farce being pressed into the service of imperial force. Indigenous populations witnessed grotesque displays of Anglo-American gendered and racial values through theatrical recreation, while simultaneously resisting the encroachment of expedition society through similar but seemingly smaller avenues of performative resistance. Broadly speaking, this project offers this more radical, revisionist interpretation at a time when interest in the Arctic and Antarctic is soaring due to anthropogenic climate change. It challenges the current reappropriation of heroic, hyper-masculine figures by national and private interests through celebrating their lesser-known but equally fascinating midwinter activities.

"Les marins aiment énormément se grimer». Travestis et blackfaces dans les explorations polaires, Ph.D., University of London, King's College, Londres (RU), 323 pages.

Ce projet de recherche s'érige contre les récits hégémoniques des explorations polaires du $\mathrm{XIX}^{\mathrm{e}}$ et du début du $\mathrm{XX}^{\mathrm{e}}$ siècles. À partir des journaux publiés ou inédits d'explorateurs, de 1819 à 1904, il interroge la façon dont la théorie critique raciale, allosexuelle et postcoloniale de l'image hypermasculine et intégralement blanche de l'explorateur polaire peut ouvrir sur de nouvelles compréhensions des espaces polaires, à la fois au XIX ${ }^{\mathrm{e}}$ siècle et de nos jours, alors que sont à l'œuvre des entreprises nationalistes et coloniales similaires. Principalement inspirée par les travaux féministes et postcoloniaux de Lisa Bloom sur l'idéologie américaine de l'exploration polaire, cette thèse évoque la grande disparité entre l'image intensément masculine du héros-aventurier au Pôle et la tendance particulièrement anglo-américaine, mais aussi norvégienne, au travestissement durant les expéditions polaires. Elle examine également à quelle fréquence les marins arboraient en spectacle des blackfaces: dans l'un des lieux les plus blancs que l'on puisse concevoir, les marins se noircissaient la figure pour exprimer la complexe constellation des griefs et des aspirations de classe dans le monde blanc colonialiste. Le théâtre polaire, qui a évolué jusqu'à avoir ses propres idiosyncrasies façonnées par l'environnement naturel et social du Pôle, a influencé les relations avec les Inuit, l'effet de la bouffonnerie étant mis au service de la force impériale. Les populations autochtones assistaient à l'exhibition grotesque 
des valeurs raciales et de genre des Anglo-américains par le biais d'un divertissement théâtral, tout en résistant en même temps à l'empiètement de la société de l'expédition par des voies similaires, mais apparemment plus modestes, de résistance performative. Au sens large, cette thèse propose cette interprétation révisionniste plus radicale à une époque où l'intérêt pour l'Arctique et l'Antarctique s'emballe sous l'effet du changement climatique anthropogène. Elle conteste la réappropriation actuelle des personnages hérö̈ques hypermasculins par des intérêts nationaux et privés au moyen de célébrations moins connues mais tout aussi fascinantes d'activités hivernales.

TOPKOK, Charles Sean Asiqluq

2015 Iñupiat Ilitqusiat: Inner Views of Our Iñupiaq Values, Ph.D., University of Alaska Fairbanks, Fairbanks, 198 pages.

Iñupiat Ilitqusiat: Inner Views of Our Iñupiaq Values examines how Iñupiat pass down elements of their cultural heritage to future generations. The research is community-driven by the Pavva Iñupiaq Dancers of Fairbanks, families with Iñupiaq children in their household, and other Iñupiat worldwide. Being myself an Iñupiaq, my doctoral research addresses how we view each Iñupiat ilitqusiat ('Iñupiaq values'), how our Iñupiat ilitqusiat have been passed down, and how we pass down our Iñupiaq cultural heritage to our future cultural-bearers. Participants talk about their Iñpiat ilitqusiat to acknowledge that they are Iñupiat wherever they live. I assert that in order to conduct culturally appropriate research with Iñupiaq people, it is imperative to observe cultural protocols and values, to equally include Indigenous narrative history and Western literature in the review process, and to observe Iñupiaq methods and methodology when gathering data. I examined and applied the ways my ancestors have gathered and presented data, formalizing for academia an Iñupiaq way of conducting research. I have conducted 17 group interviews corresponding to the 17 Iñpiat ilitqusiat. In my findings, I acknowledge that our Iñupiaq values help define our heritage. They are embedded in our lives and in our stories. They are in our spirit, passed down to us through our ancestors. Each Iñupiat ilitqusiat converges with each other when we examine how each cultural value applies to our lives. We need to continue talking about our cultural values in every village to ensure our descendants live their cultural heritage.

Iñupiat ilitqusiat. Une vision intérieure de nos valeurs iñupiaq, Ph.D., University of Alaska Fairbanks, Fairbanks, 198 pages.

Iñupiat ilitqusiat. Une vision intérieure de nos valeurs iñupiaq examine la façon dont les Iñupiat transmettent les éléments de leur patrimoine culturel aux générations futures. Cette recherche est menée au niveau communautaire par les Danseurs Pavva Iñupiaq de Fairbanks, des familles comptant des enfants iñupiaq au foyer, et d'autres Iñupiat au niveau mondial. Étant moi-même un 
Iñupiaq, ma recherche doctorale aborde la façon dont nous considérons chacune des Iñpiat ilitqusiat (valeurs iñupiaq), la façon dont celles-ci se transmettent et la façon dont nous transmettons notre patrimoine culturel iñupiaq à nos futurs porteurs de culture. En évoquant leurs Iñupiat ilitqusiat, les participants reconnaissent qu'ils sont des Iñupiat quel que soit l'endroit où ils vivent. J'affirme que pour pouvoir mener une recherche adaptée au niveau culturel auprès des Iñupiat, il est impératif de respecter les valeurs et protocoles culturels, d'inclure à parts égales les récits historiques autochtones et les travaux occidentaux dans le processus d'analyse critique, et d'observer une méthodologie et des méthodes iñupiat au moment de la collecte des données. J'ai examiné et appliqué les façons de faire de mes ancêtres dans la collecte et la présentation des données en formalisant, pour le monde universitaire, une façon iñupiaq de mener une recherche. J'ai dirigé 17 entrevues de groupes correspondant aux 17 Iñupiat ilitqusiat. Je constate, à la suite de mes découvertes, que nos valeurs iñupiat contribuent à définir notre patrimoine. Elles sont inscrites dans notre vie et dans nos histoires. Elles sont dans notre esprit, nous ayant été transmises par nos ancêtres. Les Iñupiat ilitqusiat convergent entre elles lorsque l'on examine de quelle manière chaque valeur culturelle s'applique à notre vie. Il nous faut continuer à parler de nos valeurs culturelles dans chaque village pour nous assurer que nos descendants vivront leur patrimoine culturel.

\section{VAN DEN SCOTT, Jeffrey}

2016 Music of the "True Nortb": A Study of the Interaction of Canadian Music and an Inuit Community, Ph.D., Northwestern University, Evanston, 313 pages.

The idea of the North plays a vital role in Canadian identity discourse at political, social, and artistic levels, as an imagined space and place to explore the nation's greatness. Contained within this imagined North are self-perpetuating stereotypes of Inuit-the real Northern residents who live their lives entirely within that space. The North garners attention based on political and economic gains. The North is the site of the Northwest Passage. The North is a place to be protected under the guise of Arctic sovereignty. The North is the locale of the largest Indigenous land claims settlement in the world. With each wave of interest, composers turn to the North as a source of inspiration, addressing the question of what it means to be Canadian. The North is also home to the majority of Canada's Inuit population, whose experiences transpire far removed from southern Canada and from these projections of their homeland. This dissertation brings the imagined idea of North and the real, tangible North into discourse through musical repertoire. This exercise examines the human element of the North through two lenses: that presented by Euro-Canadian composers in their interpretations and imaginings of the North since the national Centennial celebrations of 1967, and that presented by the Inuit inhabitants in the small Hamlet of Arviat, Nunavut. Adding Inuit voices complicates the discussion about the North, as the reality for 
Inuit rarely matches what composers and audiences conceive when they turn their gaze northward. The North is neither a singular place nor an historical one. It is a complex, multi-sited, living space. Providing ethnographic examples from one community does not seek to speak to the diversity of the North, but rather aims to highlight one instance that challenges the model of Canada as an imagined community, united around its Northern lands. Examining the music of the North from both perspectives allows insights into the relationship between Canada's center in the South and its periphery in the North.

La musique du "vrai Nord». Étude de l'interaction entre la musique canadienne et une communauté inuit, Ph.D., Northwestern University, Evanston, 313 pages.

L'idée du Grand Nord joue un rôle crucial dans le discours identitaire canadien, aux niveaux politique, social et artistique, en tant qu'espace imaginé et lieu d'exploration de la grandeur de la nation. Ce Grand Nord imaginaire perpétue des stéréotypes au sujet des Inuit - les véritables résidents du Nord, qui vivent toute leur vie dans cet espace. Le Grand Nord attire l'attention pour les possibilités de gains économiques et politiques qu'il renferme. Le Grand Nord est le site du Passage du Nord-Ouest. Le Grand Nord est un lieu qui doit être protégé au prétexte de la souveraineté sur l'Arctique. Dans le Grand Nord ont été rédigés les traités relatifs aux plus grandes revendications territoriales autochtones au monde. Pour chacune des vagues d'intérêt qu'il suscite, les compositeurs prennent le Grand Nord pour source d'inspiration, posant la question de ce que signifie être canadien. Le Grand Nord abrite également la majorité de la population inuit du Canada, dont l'expérience paraît bien éloignée de celle du Canada du sud et de ces représentations de leur terre natale. Cette thèse confronte l'idée du Grand Nord imaginaire et du Grand Nord réel, concret, sur le mode discursif à travers le répertoire musical. L'élément humain du Grand Nord y est examiné à travers deux prismes: celui que présentent les compositeurs euro-canadiens dans leurs interprétations et leurs représentations du Grand Nord depuis les commémorations nationales du Centenaire en 1967, et celui que présentent les habitants inuit du petit hameau d'Arviat, au Nunavut. L'apport des voix inuit rend plus complexe la discussion au sujet du Grand Nord car la réalité des Inuit correspond rarement à celle que conçoivent les compositeurs et leur public lorsqu'ils tournent les yeux vers le nord. Le Grand Nord n'est ni un lieu singulier ni un lieu historique. C'est un espace vivant, complexe, multi-sites. En apportant des exemples ethnographiques en provenance d'une communauté, nous ne cherchons pas à évoquer la diversité du Grand Nord, mais plutôt à mettre en lumière un cas de contestation du modèle du Canada en tant que communauté imaginée, unie autour de ses terres nordiques. Le fait de considérer la musique du Grand Nord à partir de ces deux perspectives nous procure des apercus de la relation entre le centre du Canada, au sud, et sa périphérie, au nord. 
WALLS, Matthew

2016 Frozen Landscapes, Dynamic Skills: An Ethnoarchaeological Study of Inuit Kayaking Enskilment and the Perception of the Environment in Greenland, Ph.D., University of Toronto, Toronto, 290 pages.

This dissertation is an ethnoarchaeological study of kayaking-a skill that has been practiced by Inuit in the Eastern Arctic since the first Thule migrants explored and settled the region around 1250 A.D. In this project, I aim to better understand the archaeological record of Inuit culture by working closely with a community in Greenland that builds kayaks and practices traditional hunting skills. Although kayaking is no longer a primary mode of subsistence, the community finds meaning in the persistence of the skill because it is an important mechanism of intergenerational experience, and because it contains types of cultural and environmental knowledge that can only exist through practice. The community is specifically focused on the physicality of enskilmentthe process through which individuals develop unique capacities for awareness and response through environmentally situated practice. Through enskilment, kayakers attune their senses to subtleties and nuances of the environment which would not otherwise be apparent, and they embody a heritage of resilience and creative responsiveness in both the natural and social environment. Drawing on three field seasons of ethnoarchaeological fieldwork, I document the process through which individuals become skilled kayakers and explore the constitution of the kayaking community through practice. As demonstrated in this dissertation, the acquisition of skill in kayaking is not a passive process where knowledge is simply handed from one generation to the other. This is an important observation for archaeologists who study the past through the interpretation of material culture. It will be argued that understanding the impermanence and inherent creativity through which environmentally situated knowledge is re-grown in the experiences of each generation allows for more nuanced archaeological narratives which emphasize skilled practice on the part of individuals as causative agents at work in the deeper history of Inuit culture.

WALLS, Matthew

2014 Gel des paysages, dynamique des aptitudes. Étude ethnoarchéologique de l'acquisition des techniques du kayak chez les Inuit et de la perception de l'environnement au Groenland, Ph.D., Université de Toronto, Toronto, 290 pages.

Cette thèse est une étude ethnoarchéologique de la pratique du kayak savoir-faire mis en pratique par les Inuit de l'Arctique de l'Est depuis que les premiers migrants thuléens ont exploré la région et s'y sont installés aux environs de 1250 de notre ère. Mon objectif ici est de mieux comprendre les données archéologiques de la culture inuit en travaillant étroitement avec une 
communauté du Groenland qui fabrique des kayaks et emploie les techniques de chasse traditionnelles. Bien que les déplacements en kayak ne constituent plus un mode de subsistance essentiel, la communauté trouve un sens à la perpétuation de ce savoir-faire, car il s'agit d'un mécanisme important d'expérience intergénérationnelle, et parce qu'il renferme certains types de savoirs culturels et relatifs à l'environnement que seule la pratique peut faire exister. La communauté se concentre en particulier sur le caractère physique de l'acquisition des aptitudes (enskilment) - le processus par lequel les individus acquièrent des capacités uniques d'évaluation du risque et de réaction par une pratique localisée dans un environnement précis. Par cette acquisition des aptitudes, les kayakistes deviennent sensibles aux subtilités et aux nuances de l'environnement qui sans cela ne leur seraient pas évidentes, et ils incorporent un patrimoine de résilience et de réactivité créative à la fois dans l'environnement social et dans l'environnement naturel. En me basant sur trois saisons de travail de terrain en ethnoarchéologie, je documente le processus par lequel les individus deviennent des kayakistes habiles et j'explore la constitution de la communauté des kayakistes par le biais de la pratique. Comme cette thèse en fait la démonstration, l'acquisition des aptitudes en kayak n'est pas un processus passif lors duquel le savoir est simplement transféré d'une génération à l'autre. Il s'agit d'une observation importante pour les archéologues qui étudient le passé par le biais de l'interprétation de la culture matérielle. La compréhension de l'impermanence et de la créativité à travers lesquelles les savoirs ancrés dans l'environnement se régénèrent, lors des expériences de chaque génération, permet des interprétations archéologiques plus nuancées. Ces dernières mettent l'accent sur la pratique expérimentée d'individus, eux-mêmes agents de causalité à l'œuvre au plus profond de l'histoire de la culture inuit. 